\title{
FOURIER IR SPECTROSCOPY STUDY OF THE RADIATION-THERMAL DECOMPOSITION OF WATER IN THE nano- $\mathrm{ZrO}_{2}+$ nano- $\mathrm{Al}_{2} \mathrm{O}_{3}+\mathrm{H}_{2} \mathrm{O}$ SYSTEM
}

\author{
T. N. Agayev, S. Z. Melikova DD, N. N. Gadzhieva \\ Institute of Radiation Problems NAS of Azerbaijan, \\ 9, B. Vahabzadeh St., Baku, AZ-1143, Azerbaijan, \\ e-mail: sevincmelikova9513@gmail.com
}

(Received 26 August 2019; in final form 27 March 2020; accepted 07 April 2020; published online 18 April 2020)

\begin{abstract}
This paper presents the results of Fourier transform infrared spectroscopic studies of the radiationthermal decomposition of water in the heterogeneous system nano- $\mathrm{ZrO}_{2}+$ nano- $\mathrm{Al}_{2} \mathrm{O}_{3}+\mathrm{H}_{2} \mathrm{O}$ at various weight ratios of nano-oxides in the temperature range $T=373 \div 673 \mathrm{~K}$ and during radiation exposure. It has been established that the main intermediate products of radiation-heterogeneous decomposition of water are molecular oxygen and other oxygen-containing radical ion groups generated by gamma irradiation, as well as surface hydrides of zirconium and aluminum. Based on a comparative analysis of changes in the intensity of the absorption bands of molecular water and surface hydroxyl groups characterizing nano- $\mathrm{ZrO}_{2}$ and nano- $\mathrm{Al}_{2} \mathrm{O}_{3}$ as a function of temperature, the radiation-catalytic activity of nano- $\mathrm{ZrO}_{2}$ was detected at a fixed value of the absorbed dose. $W_{\mathrm{RT}}$ $\left(\mathrm{H}_{2}\right)$ and its radiation-chemical yields $G\left(\mathrm{H}_{2}\right)$ were determined. A stimulating role in the radiationthermal decomposition of $\mathrm{H}_{2} \mathrm{O}$ in a heterogeneous nano- $\mathrm{ZrO}_{2}+$ nano- $\mathrm{Al}_{2} \mathrm{O}_{3}$ system $(T=373 \div 673 \mathrm{~K})$ has been established.
\end{abstract}

Key words: Fourier IR spectroscopy, nano-zirconium oxide, nano-aluminum oxide, $\gamma$-irradiation, radiation-thermal decomposition.

DOI: https://doi.org/10.30970/jps.24.2701

\section{INTRODUCTION}

Nanosized aluminum and zirconium oxide compounds are widely used as active components and an effective carrier of catalysts in various processes, including radiation-catalytic processes of hydrogen production from water [1-6]. Zirconium and aluminum oxides are also technologically important materials in the field of manufacturing ceramics, solid electrolytes, radiation detectors and materials for space and nuclear technologies. As it is known, reducing a particle size to nanoscale leads to a significant change in physical properties [34]. The dimensions of individual nanooxide particles are comparable to the mean free path of electrons, holes, and excited states produced by the action of ionizing radiation, which participate in the effective transformation and transfer of energy. To modify the physical and chemical properties, materials based on mixtures of nanoscale oxides are produced [7-9].

As a result of the interaction between the components, the concentration of surface acceptor centers changes, as well as the mechanical and physical properties of the components of the system. Information on the effect of the second component on the surface physical and chemical and radiation-catalytic properties of the binary system of nano- $\mathrm{ZrO}_{2}+$ nano- $\mathrm{Al}_{2} \mathrm{O}_{3}+\mathrm{H}_{2} \mathrm{O}$ is limited. In the literature there is virtually no spectroscopic data on the radiation decomposition of water in a nano$\mathrm{ZrO}_{2}+$ nano- $\mathrm{Al}_{2} \mathrm{O}_{3}+\mathrm{H}_{2} \mathrm{O}$ system.

This paper presents the results of Fourier IR spectroscopic studies of the radiation-thermal decomposition of water in a heterogeneous system of nano- $\mathrm{ZrO}_{2}+$ nano- $\mathrm{Al}_{2} \mathrm{O}_{3}+\mathrm{H}_{2} \mathrm{O}$, in the temperature range $T=373 \div 673 \mathrm{~K}$ under the influence of $\gamma$-quanta, in order to establish the role of intermediate-active parti- cles and to reveal the regularities of adsorption-active hydroxyl groups in these processes.

\section{EXPERIMENTAL PART}

$\mathrm{ZrO}_{2}$ (particle size $d=20-30 \mathrm{~nm}$ ) and $\mathrm{Al}_{2} \mathrm{O}_{3}$ (particle size $d=20-60 \mathrm{~nm}$ ) nanopowders with a purity of $99.9 \%$ (Sky Spring Nanomaterials, USA) were used. The Xray phase method established that the $\mathrm{ZrO}_{2}$ sample has a monoclinic centrally symmetric crystal structure [10]. By the X-ray phase method, it was established that the nano- $\mathrm{ZrO}_{2}$ sample has a monoclinic centrally symmetric crystal structure, and the nano- $\mathrm{Al}_{2} \mathrm{O}_{3}$ has -modification of the cubic structure. The values of specific surfaces are $S_{\mathrm{sp}}\left(\right.$ nano- $\left.\mathrm{ZrO}_{2}\right)=350 \mathrm{~m}^{2} / \mathrm{g}$ and $S_{\mathrm{sp}}\left(\right.$ nano- $\left.\mathrm{Al}_{2} \mathrm{O}_{3}\right)=$ $280 \mathrm{~m}^{2} / \mathrm{g}$. Before adsorption, samples of zirconium and aluminum dioxides were treated by thermovacuum at $T=673 \mathrm{~K}$ and pressure $P=10^{-3} \mathrm{~Pa}$ for $8 \mathrm{~h}$ for cleaning from organic impurities and dehydroxylation of surfaces. The control over the surface cleanliness was carried out according to the intensity of IR bands caused by water and hydrocarbon contamination.

Fourier IR absorption spectra were recorded on a Varian 640 FTIR spectrometer in the frequency range $\nu=4000-400 \mathrm{~cm}^{-1}$ at room temperature. To remove the absorption spectra from a mixture of $\mathrm{ZrO}_{2}+\mathrm{Al}_{2} \mathrm{O}_{3}$ nanopowders, pellets with a thickness of $50 \div 100 \mu \mathrm{m}$ were pressed. The IR spectra of the samples were measured in special quartz cells with windows made of $\mathrm{CaF}_{2}$, which made it possible to obtain spectra of adsorbed water, decomposed under the action of $\gamma$-irradiation by the method of [10]. The ratio of nanooxide components varied as $3: 1,1: 1$ and 1:3. When overlapping the bands related to different forms of adsorbed water and hydroxyl 
groups, the total contour is decomposed into individual components according to the procedure [5]. This technique includes a program that takes into account the specificity of adsorbed molecules at the interface of the adsorbent-adsorbate. The intensities of the bands of adsorbed water molecules and hydroxyl groups in the systems under study were calculated. The values of the intensities given are the arithmetic average values obtained in four parallel independent experiments.

The adsorbate was bidistilled water, from which foreign gases were removed by repeated freezing in a trap with liquid nitrogen followed by pumping out. Adsorption of water vapor was studied by the method of [10]. The radiative decomposition of water in the system of nano- $\mathrm{ZrO}_{2}+$ nano- $\mathrm{Al}_{2} \mathrm{O}_{3}+\mathrm{H}_{2} \mathrm{O}$ was carried out at room temperature $(T=300 \mathrm{~K})$. Samples were irradiated on an isotope ${ }^{60} \mathrm{Co}$ source with a dose rate $d D_{\gamma} / d t=$ $0.14 \mathrm{~Gy} / \mathrm{s}$. The dosimetry of the source was carried out by ferrosulfate and methane dosimeters [11]. The absorbed dose of irradiation in the systems under investigation was determined by comparing the electron densities and was $D_{\gamma}=30 \mathrm{kGy}$.

\section{RESULTS AND THEIR DISCUSSION}

The IR spectrum of a mixture of nano- $\mathrm{ZrO}_{2}+$ nano$\mathrm{Al}_{2} \mathrm{O}_{3}$ at a 1:1 ratio is shown in Fig. 1 (curve 1) and for nano- $\mathrm{ZrO}_{2}+$ nano- $\mathrm{Al}_{2} \mathrm{O}_{3}+\mathrm{H}_{2} \mathrm{O}$ system - in Fig. 1 (curve $2)$. Then $\gamma$-irradiation of nano- $\mathrm{ZrO}_{2}+$ nano- $\mathrm{Al}_{2} \mathrm{O}_{3}+\mathrm{H}_{2} \mathrm{O}$ systems was performed at same doses (curve 3), (curve 4 ) and $D_{\gamma}=30 \mathrm{kGy}$ (curve 5). As can be seen from Fig. 1 (curve 1), the surface of a nano- $\mathrm{ZrO}_{2}+$ nano- $\mathrm{Al}_{2} \mathrm{O}_{3}$ mixture, which has undergone thermovacuum treatment, is pure, since there are no absorption bands due to the presence of water and hydrocarbon contaminants.

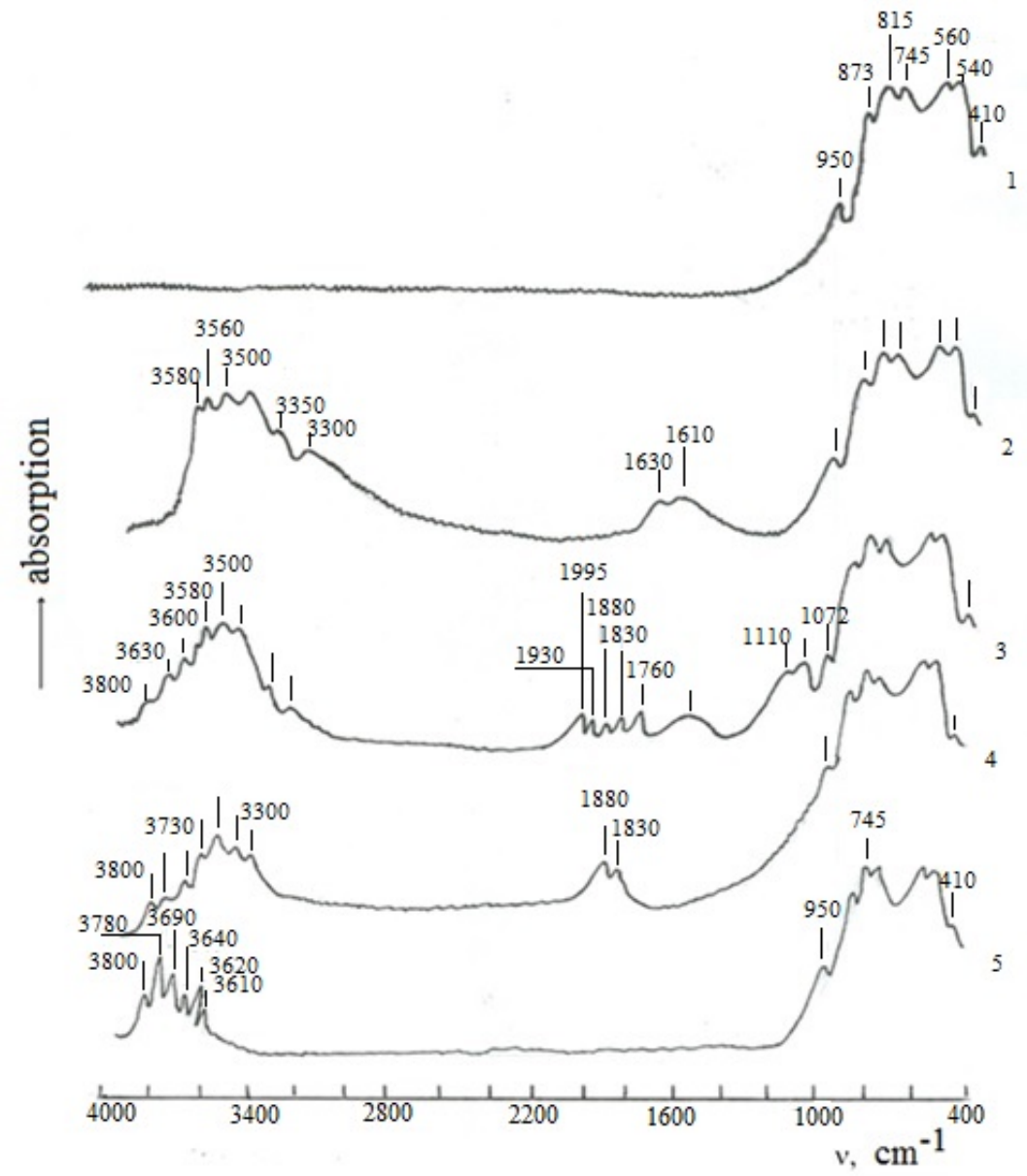

Fig. 1. Fourier IR spectra of nano- $\mathrm{ZrO}_{2}+$ nano- $\mathrm{Al}_{2} \mathrm{O}_{3}$, mixture, processed at $673 \mathrm{~K}(1)$, up to (2) and after the action of $\gamma$ irradiation on the system of nano- $\mathrm{ZrO}_{2}+$ nano- $\mathrm{Al}_{2} \mathrm{O}_{3}+\mathrm{H}_{2} \mathrm{O}$ at $373(3), 473$ (4) and $673 \mathrm{~K}(5)$. The spectra were obtained with a weight ratio of nanooxide components (1:1) at a fixed dose of $\mathrm{D}_{\gamma}=30 \mathrm{kGy}$.

Absorption bands with maxima at 950, 873, 815, 745, 560,540 , and $410 \mathrm{~cm}^{-1}$ were observed in the spectra, in the region of lattice vibrations of nano- $\mathrm{ZrO}_{2}$ and nano$\mathrm{Al}_{2} \mathrm{O}_{3}$. The $745 \mathrm{~cm}^{-1}$ band is referred to the asymmetric vibration $\left(\mathrm{Zr}-\mathrm{O}_{2}-\mathrm{Zr}\right)[3,4]$. The location and intensity ratio of absorption bands $(\mathrm{AB})$ at $745-410 \mathrm{~cm}^{-1}$ indicate a monoclinic modification of the $\mathrm{ZnO}_{2}$ nanopowder used [10]. The absorption bands refer to the stretching 
vibration of $\mathrm{Al}-\mathrm{O}$, and the $\mathrm{ABs}$ at $873,815,560$ and $540 \mathrm{~cm}^{-1}$ are apparently related to the presence of $\mathrm{AlO}_{3}$ and $\mathrm{AlO}_{6}$-groups $[1,3]$. In studying adsorption processes and radiation-thermal decomposition of water, the lattice vibrations of zirconium and aluminum oxides and the constancy of their intensities are among the main criteria for the identification of the experimental conditions.

In the unirradiated heterosystem (nano- $\mathrm{ZrO}_{2}+$ nano$\mathrm{Al}_{2} \mathrm{O}_{3}$ ), after water adsorption ABs (Fig. 1, curve 1) with maxima 3580, 3560, appear in the region of stretching vibrations of hydroxyl (OH) groups $3500,3450,3350$, 3300,3280 and $3000 \mathrm{~cm}^{-1}$, which indicates the flow of molecular and dissociative adsorption. The molecular form of adsorption corresponds to broad absorption bands at 3280 and $3300 \mathrm{~cm}^{-1}$, while dissociative chemisorption corresponds to relatively narrow bands with maxima at $3580,3560,3500,3450,3350$, and $3300 \mathrm{~cm}^{-1}$ (Fig. 1, curve 2). The presence of the two types of adsorption is confirmed by the formation of $\mathrm{ABs}$ in the region of $\mathrm{OH}$ deformation vibrations with centers of gravity at 1630 and $1610 \mathrm{~cm}^{-1}$.

The irradiation of a heterosystem of nano- $\mathrm{ZrO}_{2}+$ nano$\mathrm{Al}_{2} \mathrm{O}_{3}+\mathrm{H}_{2} \mathrm{O}$ by $\gamma$-quanta (an absorption dose of $D_{\gamma}=$ $30 \mathrm{kGy}$ at the temperature of $T=373 \mathrm{~K}$ ) is accompanied by the appearance of new ABs in the $800-1000 \mathrm{~cm}^{-1}$ region with maxima at $1072,1085,1110 \mathrm{~cm}^{-1}$, are associated which adsorption of molecular oxygen - the product of water decomposition on the surface of nano-oxides $\mathrm{ZrO}_{2}$ and $\mathrm{Al}_{2} \mathrm{O}_{3}$, indicating the formation of ion radicals of oxygen in the $\pi$-form, i. e. $\mathrm{O}^{2-}$.

Thus, Fourier IR spectroscopy allows recording the intermediate products of the radiation-thermal decomposition of water in the system of nano$\mathrm{ZrO}_{2}+$ nano- $\mathrm{Al}_{2} \mathrm{O}_{3}+\mathrm{H}_{2} \mathrm{O}$ on the oxide surface. Among these products, surface zirconium and aluminum hydrides are most intense. Thus, starting from the temperature of $T=373 \mathrm{~K}$ in the spectrum, in the frequency range $2000-1700 \mathrm{~cm}^{-1}$ there appear ABs appear with maxima at 1760, 1830, 1880, 1920 and $1995 \mathrm{~cm}^{-1}$, whose intensities are redistributed with the growth of temperature. These ABs refer to the stretching vibrations of $\mathrm{Zr}-\mathrm{H}$ and $\mathrm{Al}-\mathrm{H}$, indicating the formation of surface hydrides of the $\mathrm{Zr}-\mathrm{H}, \mathrm{ZrH}_{2}, \mathrm{Al}-\mathrm{H}, \mathrm{Al}-\mathrm{H}_{2}$ and $\mathrm{Al}-$ $\mathrm{H}_{3}$ types. Among these hydrides, the most stable forms are $\mathrm{ZrH}_{2}\left(\nu=880 \mathrm{~cm}^{-1}\right)$ and $\mathrm{AlH}_{3}\left(\nu=1830 \mathrm{~cm}^{-1}\right)$ [12-14].

Changes in the valence vibrations of hydroxyl $(\mathrm{OH})$ groups associated with the radiation-thermal decomposition of water in a heterogeneous system of nano$\mathrm{ZrO}_{2}+$ nano- $\mathrm{Al}_{2} \mathrm{O}_{3}+\mathrm{H}_{2} \mathrm{O}$ are shown in Fig. 1 (curves $3-5)$. In the Fourier IR absorption spectra of samples of a nano- $\mathrm{ZrO}_{2}+$ nano- $\mathrm{Al}_{2} \mathrm{O}_{3}$ mixture with adsorbed water, in the region of stretching vibrations of $\mathrm{OH}$ groups and water $\left(\nu=4000-3000 \mathrm{~cm}^{-1}\right)$, the ABs of hydrogen bonded groups with maxima at 3580,3500 and 3450 $\mathrm{cm}^{-1}$, as well as adsorbed water molecules at $3280 \mathrm{~cm}^{-1}$ are observed (Fig. 1, curve 3).

The radiation-thermal decomposition of water at $T=$ $373 \mathrm{~K}$ is accompanied by a decrease in the intensities of the ABs of molecular water and hydrogen-bonded hydroxyl groups, as well as the formation of new bands of isolated $\mathrm{OH}$ groups at 3630 and $3690 \mathrm{~cm}^{-1}$.

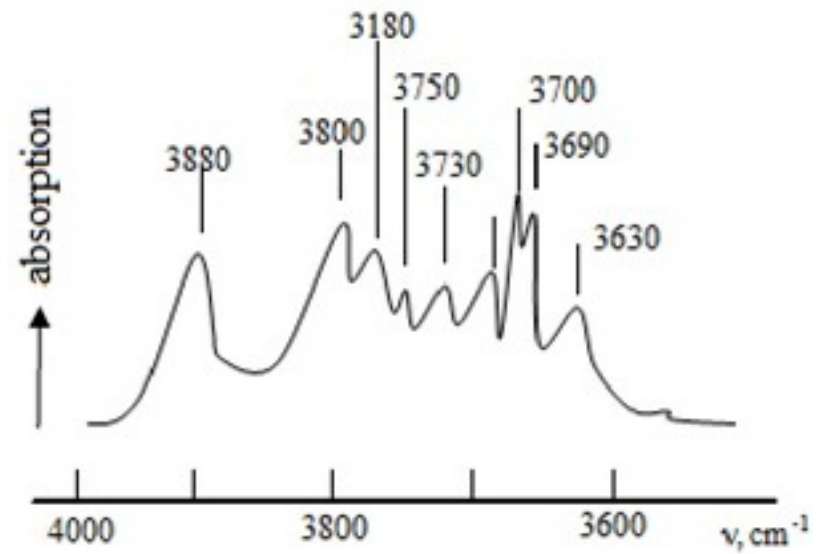

Fig. 2. Absorption bands region of the isolated $\mathrm{OH}$ groups in the nano- $\mathrm{ZrO}_{2}+$ nano- $\mathrm{Al}_{2} \mathrm{O}_{3}$ system to the $\mathrm{Zr}$ and $\mathrm{Al}$ oxides.

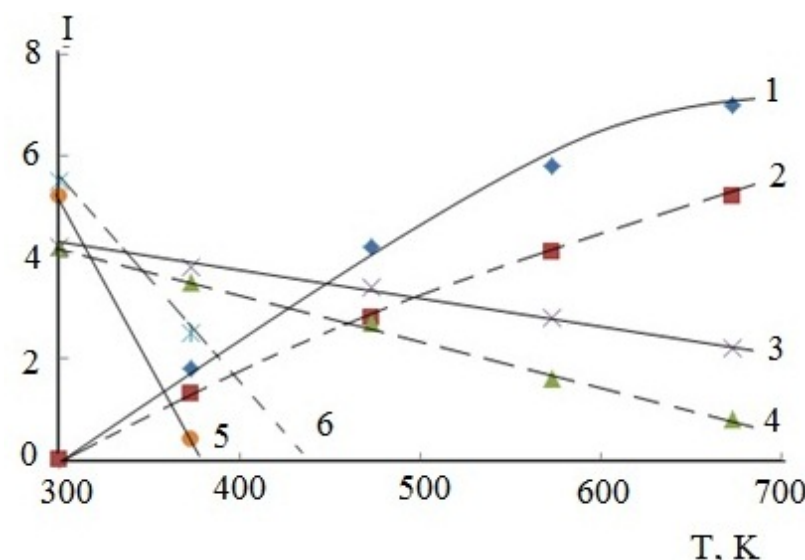

Fig. 3. Dependences of the intensities of bands of isolated $(1,2)$ and hydrogen-bonded $(3,4)$ surface $\mathrm{OH}$ groups, as well as adsorbed water molecules $(5,6)$ on the temperature of radiation-thermal processes of water decomposition in the heterogeneous system of nano- $\mathrm{ZrO}_{2}+$ nano- $\mathrm{Al}_{2} \mathrm{O}_{3}+\mathrm{H}_{2} \mathrm{O}$ (the dependences for nano- $\mathrm{ZrO}_{2}$ are shown by solid lines, and for nano- $\mathrm{Al}_{2} \mathrm{O}_{3}$-by dotted lines $),\left(D_{\gamma}=30 \mathrm{kGy}\right)$.

An increase in temperature to $473 \mathrm{~K}$ is accompanied by a decrease in the intensity of $\mathrm{H}$-bound and an increase in the intensity of bands of isolated $\mathrm{OH}$ groups at 3630 and $3690 \mathrm{~cm}^{-1}$ (Fig. 1, curve 4). The temperature rise up to $673 \mathrm{~K}$ leads to complete decay of molecular water and partial decay of $\mathrm{H}$-bonded $\mathrm{OH}$ groups (curves $3-5$ ). At $T=473 \mathrm{~K}$, new $\mathrm{AB}$ appear in the IR spectrum at 3780 and $3800 \mathrm{~cm}^{-1}$. According to the notions of the structure of hydroxyl nano oxides of zirconium and aluminum [2, 15-16], the observed new bands correspond to hydroxyl groups differing in coordination numbers. For example, according to the concept of the structure of the hydroxyl coating of nano zirconium oxide, the observed new ABs correspond to hydroxyl groups that differ in coordination number: terminal, i.e. isolated $\mathrm{OH}$ groups of type $\mathrm{I}$, isolated on $\mathrm{Zr}$ cations (AB $3780 \mathrm{~cm}^{-1}$ ), two coordinated bridging types II (AB $\left.3750 \mathrm{~cm}^{-1}\right)$ and three coordinated 
bridging types III (AB 3640 and $3690 \mathrm{~cm}^{-1}$ ). According to [10], these ABs can be attributed to the hydroxyl groups of $\mathrm{ZrO}_{2}$, mainly in the surface areas with the (111) and (110) face structure of the fluorite-like modification. Note that in the IR spectra of $\mathrm{ZrO}_{2}$ dispersed powders with micro-sized particles, only isolated $\mathrm{OH}$ groups of types I and II were detected. According to [12], in nano-aluminum oxide, depending on the coordination number, there are also isolated hydroxyl groups of 3 types: isolated $\mathrm{OH}$-type group I (AB $\left.3880,3800 \mathrm{~cm}^{-1}\right)$, type II $\left(\mathrm{AB} 3770 \mathrm{~cm}^{-1}\right)$ and type III (AB 3730, 3700 $\left.\mathrm{cm}^{-1}\right)$. To identify spectrokinetic patterns, i.e. changes in the intensities of $\mathrm{ABs}$ of molecular water and surface $\mathrm{OH}$ groups, depending on the processing temperature, the IR absorption spectra of their regions were obtained under special recording conditions. As an example, Fig. 2 shows the $\mathrm{AB}$ region of the $\mathrm{OH}$ groups that appear during the radiolysis of water in the nano- $\mathrm{ZrO}_{2}+$ nano$\mathrm{Al}_{2} \mathrm{O}_{3}$ system to the $\mathrm{Zr}$ and $\mathrm{Al}$ oxides. Nine absorption bands with good resolution are clearly visible, four of which (AB 3780, 3750, 3690 and $3640 \mathrm{~cm}^{-1}$ ) are associated with $\mathrm{ZrO}_{2}$, and five (AB 3880, 3800, 3770, 3730 and $3700 \mathrm{~cm}^{-1}$ ) with $\mathrm{Al}_{2} \mathrm{O}_{3}$.

The analysis of the changes in the intensities of the ABs of molecular water, H-bound and isolated hydroxyl groups at a fixed dose of radiation $\left(D_{\gamma}=30 \mathrm{kGy}\right)$, depending on the temperature of the process of the radiation-thermal decomposition of water, shows that there are antibate dependencies between them. Thus, an increase in temperature from 473 to $673 \mathrm{~K}$ leads to the complete and partial decomposition of molecular water and $\mathrm{H}$-bonded $\mathrm{OH}$ groups and the formation of isolated $\mathrm{OH}$ groups. This leads to a decrease in the intensity of $\mathrm{H}$-bound and, vice versa, to an increase in the intensity of isolated $\mathrm{OH}$ groups.

Figure 3 shows the dependences of the AB intensities on the temperature for isolated (at 3690 and $3700 \mathrm{~cm}^{-1}$ (curves 1,2)) and hydrogen-bonded (at 3450 and $3500 \mathrm{~cm}^{-1}$ (curves 3, 4)) surface OH-groups, as well as adsorbed water molecules (at 3280 and $3300 \mathrm{~cm}^{-1}$ (curves 5,6)) during the radiation-thermal decomposition of water in the heterogeneous system of nano- $\mathrm{ZrO}_{2}+$ nano- $\mathrm{Al}_{2} \mathrm{O}_{3}+\mathrm{H}_{2} \mathrm{O}$. Solid lines show the dependence for nano- $\mathrm{ZrO}_{2}$, and the dashed lines - for nano- $\mathrm{Al}_{2} \mathrm{O}_{3}$. Comparing these relationships, we see that an increase in temperature from 373 to $673 \mathrm{~K}$ leads to antibate dependences of $\mathrm{H}$-bound and isolated surface hydroxyl groups. Changes in the ratio of the concentrations of $\mathrm{ZrO}_{2}$ and $\mathrm{Al}_{2} \mathrm{O}_{3}$ nanopowders (1:3, 1:1 and 3:1) in the Fourier IR absorption spectra are accompanied by a redistribution of the intensities of the ABs of molecular water, $\mathrm{H}$-bonded and isolated $\mathrm{OH}$ groups.

\begin{tabular}{|c|c|c|c|c|c|}
\hline No. & System & $T, \mathrm{~K}$ & $\begin{array}{c}W_{\mathrm{T}}\left(\mathrm{H}_{2}\right) \\
\text { molecule } / \mathrm{g} \cdot \mathrm{s}\end{array}$ & $\begin{array}{c}W_{\mathrm{RT}}\left(\mathrm{H}_{2}\right) \\
\text { molecule } / \mathrm{g} \cdot \mathrm{s}\end{array}$ & $\begin{array}{c}G\left(\mathrm{H}_{2}\right) \\
\text { molecule } / 100 \mathrm{eV}\end{array}$ \\
\hline 1 & $\mathrm{n}-\mathrm{ZrO}_{2}$ & \multirow{5}{*}{373} & $1.0 \cdot 10^{13}$ & $5 \cdot 10^{13}$ & 4.5 \\
\hline 2 & $\mathrm{n}-\mathrm{Al}_{2} \mathrm{O}_{3}$ & & $0.69 \cdot 10^{13}$ & $2.78 \cdot 10^{13}$ & 2.75 \\
\hline 3 & $\mathrm{n}-\mathrm{ZrO}_{2}+\mathrm{n}-\mathrm{Al}_{2} \mathrm{O}_{3}(3: 1)$ & & $0.84 \cdot 10^{13}$ & $4.2 \cdot 10^{13}$ & 4.0 \\
\hline 4 & $\mathrm{n}-\mathrm{ZrO}_{2}+\mathrm{n}-\mathrm{Al}_{2} \mathrm{O}_{3}(1: 1)$ & & $0.67 \cdot 10^{13}$ & $3.34 \cdot 10^{13}$ & 3.1 \\
\hline 5 & $\mathrm{n}-\mathrm{ZrO}_{2}+\mathrm{n}-\mathrm{Al}_{2} \mathrm{O}_{3}(1: 3)$ & & $0.51 \cdot 10^{13}$ & $2.91 \cdot 10^{13}$ & 2.7 \\
\hline
\end{tabular}

Table 1. Values of formation rates $W\left(\mathrm{H}_{2}\right)$ and of chemical yields of molecular hydrogen $G\left(\mathrm{H}_{2}\right)$ at radiation-thermal (RT) and thermal $(\mathrm{T})$ decomposition of water into nano- $\mathrm{ZrO}_{2}$, nano- $\mathrm{Al}_{2} \mathrm{O}_{3}$ and binary system of nano- $\mathrm{ZrO}_{2}+$ nano- $\mathrm{Al}_{2} \mathrm{O}_{3}$ at temperature $T=373 \mathrm{~K}$.

\begin{tabular}{|c|c|c|c|c|c|}
\hline No. & System & $T, \mathrm{~K}$ & $\begin{array}{c}W_{\mathrm{T}}\left(\mathrm{H}_{2}\right) \\
\text { molecule } / \mathrm{g} \cdot \mathrm{s}\end{array}$ & $\begin{array}{c}W_{\mathrm{RT}}\left(\mathrm{H}_{2}\right) \\
\text { molecule } / \mathrm{g} \cdot \mathrm{s}\end{array}$ & $\begin{array}{c}G\left(\mathrm{H}_{2}\right) \\
\text { molecule } / 100 \mathrm{eV}\end{array}$ \\
\hline 1 & $\mathrm{n}-\mathrm{ZrO}_{2}$ & \multirow{5}{*}{473} & $5.56 \cdot 10^{13}$ & $2.08 \cdot 10^{14}$ & 8.35 \\
\hline 2 & $\mathrm{n}-\mathrm{Al}_{2} \mathrm{O}_{3}$ & & $2.22 \cdot 10^{13}$ & $5.83 \cdot 10^{13}$ & 4.15 \\
\hline 3 & $\mathrm{n}-\mathrm{ZrO}_{2}+\mathrm{n}-\mathrm{Al}_{2} \mathrm{O}_{3}(3: 1)$ & & $5.02 \cdot 10^{13}$ & $1.81 \cdot 10^{14}$ & 7.5 \\
\hline 4 & $\mathrm{n}-\mathrm{ZrO}_{2}+\mathrm{n}-\mathrm{Al}_{2} \mathrm{O}_{3}(1: 1)$ & & $4.45 \cdot 10^{13}$ & $1.0 \cdot 10^{14}$ & 6.7 \\
\hline 5 & $\mathrm{n}-\mathrm{ZrO}_{2}+\mathrm{n}-\mathrm{Al}_{2} \mathrm{O}_{3}(1: 3)$ & & $2.57 \cdot 10^{13}$ & $6.78 \cdot 10^{13}$ & 4.8 \\
\hline
\end{tabular}

Table 2. Values of formation rates $W\left(\mathrm{H}_{2}\right)$ and of chemical yields of molecular hydrogen $G\left(\mathrm{H}_{2}\right)$ at radiation-thermal (RT) and thermal $(\mathrm{T})$ decomposition of water into nano- $\mathrm{ZrO}_{2}$, nano- $\mathrm{Al}_{2} \mathrm{O}_{3}$ and binary system of nano- $\mathrm{ZrO}_{2}+$ nano- $\mathrm{Al}_{2} \mathrm{O}_{3}$ at temperature $T=473 \mathrm{~K}$.

The decomposition of hydrogen-bonded hydroxyl groups is accompanied by the accumulation of isolated surface $\mathrm{OH}$ groups. Under radiation-thermal action, the water desorption process is correlated by the decay of $\mathrm{H}$-bound and the accumulation of isolated surface $\mathrm{OH}$ groups for nano- $\mathrm{ZrO}_{2}$, which is much more effective than nano- $\mathrm{Al}_{2} \mathrm{O}_{3}[17,18]$. This indicates the catalytic activity of nano- $\mathrm{ZrO}_{2}$ in the process of the radiation-thermal decomposition of water in the heterogeneous system of nano- $\mathrm{ZrO}_{2}+$ nano- $\mathrm{Al}_{2} \mathrm{O}_{3}+\mathrm{H}_{2} \mathrm{O}$ in the temperature interval $T=373 \div 673 \mathrm{~K}$. 


\begin{tabular}{|c|c|c|c|c|c|}
\hline No. & System & $T, \mathrm{~K}$ & $\begin{array}{c}W_{\mathrm{T}}\left(\mathrm{H}_{2}\right) \\
\text { molecule } / \mathrm{g} \cdot \mathrm{s}\end{array}$ & $\begin{array}{c}W_{\mathrm{RT}}\left(\mathrm{H}_{2}\right) \\
\text { molecule } / \mathrm{g} \cdot \mathrm{s}\end{array}$ & $\begin{array}{c}G\left(\mathrm{H}_{2}\right) \\
\text { molecule } / 100 \mathrm{eV}\end{array}$ \\
\hline 1 & $\mathrm{n}-\mathrm{ZrO}{ }_{2}$ & \multirow{5}{*}{673} & $2.78 \cdot 10^{14}$ & $6.94 \cdot 10^{14}$ & 24.7 \\
\hline 2 & $\mathrm{n}-\mathrm{Al}_{2} \mathrm{O}_{3}$ & & $4.17 \cdot 10^{13}$ & $9.44 \cdot 10^{13}$ & 8.6 \\
\hline 3 & $\mathrm{n}-\mathrm{ZrO}_{2}+\mathrm{n}-\mathrm{Al}_{2} \mathrm{O}_{3}(3: 1)$ & & $2.59 \cdot 10^{14}$ & $4.45 \cdot 10^{14}$ & 21.2 \\
\hline 4 & $\mathrm{n}-\mathrm{ZrO}_{2}+\mathrm{n}-\mathrm{Al}_{2} \mathrm{O}_{3}(1: 1)$ & & $1.52 \cdot 10^{14}$ & $2.61 \cdot 10^{14}$ & 12.9 \\
\hline 5 & $\mathrm{n}-\mathrm{ZrO}_{2}+\mathrm{n}-\mathrm{Al}_{2} \mathrm{O}_{3}(1: 3)$ & & $1.17 \cdot 10^{14}$ & $1.93 \cdot 10^{14}$ & 8.1 \\
\hline
\end{tabular}

Table 3. Values of formation rates $W\left(\mathrm{H}_{2}\right)$ and of chemical yields of molecular hydrogen $G\left(\mathrm{H}_{2}\right)$ at radiation-thermal (RT) and thermal (T) decomposition of water into nano- $\mathrm{ZrO}_{2}$, nano- $\mathrm{Al}_{2} \mathrm{O}_{3}$ and binary system of nano- $\mathrm{ZrO}_{2}+$ nano- $\mathrm{Al}_{2} \mathrm{O}_{3}$ at temperature $T=673 \mathrm{~K}$.

Tables 1-3 show the experimentally obtained values of the rate of formation of the final decomposition product of molecular hydrogen $\left(\mathrm{H}_{2}\right)$ for the thermal and radiation-thermal processes of the decomposition of $W_{\mathrm{T}}\left(\mathrm{H}_{2}\right)$ and $W_{\mathrm{RT}}\left(\mathrm{H}_{2}\right)$, as well as its yields $G\left(\mathrm{H}_{2}\right)$ in depending on the ratio of $\mathrm{ZrO}_{2}$ and $\mathrm{Al}_{2} \mathrm{O}_{3}$ nanopowders at different temperatures $(\mathrm{T}=373,473$ and $673 \mathrm{~K})$. As can be seen from the tables, the highest values of $G\left(\mathrm{H}_{2}\right)$ in this system are observed at the concentration of 75 wt. $\%$ nano- $\mathrm{ZrO}_{2}(3: 1)$, which is due to the most active surface-active centers of the type $\mathrm{Zr}^{4+}$. A comparative analysis of the values of $W\left(\mathrm{H}_{2}\right)$ and $G\left(\mathrm{H}_{2}\right)$ shows that in the temperature range $T=373 \div 673 \mathrm{~K}$, the rates and yields of the formation of $\mathrm{H}_{2}$ in the $\mathrm{RT}$ processes are significantly higher compared with the $\mathrm{T}$ process. This indicates the stimulating role of radiation in these processes [19].

\section{CONCLUSION}

The radiation-thermal decomposition of water in the nano- $\mathrm{ZrO}_{2}+$ nano- $\mathrm{Al}_{2} \mathrm{O}_{3}+\mathrm{H}_{2} \mathrm{O}$ heterosystem in the temperature range $373 \div 673 \mathrm{~K}$ at the ratio of nano-oxides
(3:1, 1:1 and 1:3) was studied by Fourier IR spectroscopy and at a fixed value of the absorbed dose $\left(D_{\gamma}=30 \mathrm{kGy}\right)$. It is shown that the adsorption of water in a mixture of nano-oxides of zirconium and aluminum occurs by molecular and dissociative mechanisms.

The intermediate products of the radiationheterogeneous decomposition of water are ion-radicals of molecular oxygen, surface hydrides of zirconium and aluminum, as well as hydroxyl groups. Dependences of the intensities of absorption bands of molecular water and surface hydrogen-bonded and isolated hydroxyl groups characterizing nano- $\mathrm{ZrO}_{2}$ and nano- $\mathrm{Al}_{2} \mathrm{O}_{3}$ on temperature have been studied. Based on a comparative analysis of these relationships, the radiation-catalytic activity of nano- $\mathrm{ZrO}_{2}$ in the radiation-thermal process of water decomposition has been revealed.

The values of the rates of formation of $W\left(\mathrm{H}_{2}\right)$ and the radiation-chemical yields of molecular hydrogen $G\left(\mathrm{H}_{2}\right)$ during the radiation-thermal and thermal decomposition of water into nano- $\mathrm{ZrO}_{2}$, nano- $\mathrm{Al}_{2} \mathrm{O}_{3}$ and the binary system of nano- $\mathrm{ZrO}_{2}+$ nano- $\mathrm{Al}_{2} \mathrm{O}_{3}$ were determined. The stimulating role of radiation during the radiolysis of $\mathrm{H}_{2} \mathrm{O}$ in the temperature range $T=373 \div 673 \mathrm{~K}$ has been established.
[1] A. N. Kharlamov et al., J. Phys. Chem. 68, 692 (1994).

[2] E. V. Lunina, Catalysis, Fundamental and Applied Research (MGU, Moscow, 1987).

[3] F. D. Chukin, The Structure of Aluminum Oxide and Hydrodesulphurization Catalysts. Reaction Mechanisms (Printing house Paladin, Moscow, 2010).

[4] A. A. Garibov et al., Probl. Atom. Sci. Technol. 5, 48 (2015).

[5] H. Miyata et al., Appl. Spectroscop. 40, 1177 (1986); https://doi.org/10.1366/0003702864507620.

[6] S. Seino et al., Nucl. Sci. Technol. 38, 633 (2001); https : //doi.org/10.1080/18811248.2001.9715076.

[7] N. G. Petric et al., J. Phys. Chem. B 105, 5935 (2001); https://doi.org/10.1021/jp004440o.

[8] S. Seino et al., Mater. Res. Soc. Symp. Proc. 608, 505 (2011); https://doi.org/10.1557/PROC-608- 505.

[9] A. A. Garibov et al., Nanotechnol. Russia 12, 252 (2017); https://doi.org/10.1134/S1995078017030077.

[10] T. N. Agayev et al., High Energy Chem. 52, 145(2018); https://doi.org/10.1134/S0018143918020029.
[11] A. K. Pikaev, Dosimetry in Radiation Chemistry (Nauka, Moscow, 1975).

[12] I. S. Kuchuk et al., Nanosyst.: Phys. Chem. Math. 3, 123 (2012).

[13] A. A. Garibov et al., High Energy Chem. 48, 281(2014); https://doi .org/10.1134/S0018143914030059.

[14] A. A. Davydov, IR Spectroscopy in the Chemistry of Oxide Surfaces (Nauka, Novosibirsk, 1984).

[15] A. N. Kharlamov et al., Vestn. Mosk. Univ. Ser. 2: Khim. 39, 29 (1998).

[16] M. M. Mikhailov et al., J. Surf. Invest. X-ray Synchrotron Neutron Techn. 3, 950(2009); https://doi .org/10 $.1134 / \mathrm{s} 1027451009060184$.

[17] T. Yoshida et al., Nucl. Sci. Eng. 150, 357(2005); https: //doi.org/10.13182/nse05-a2522.

[18] R. M. Belekar et al., Int. J. Res. Eng. Technol. 2, 145 (2014)

[19] O. V. Almyasheva et al., Russ. J. Appl. Chem. 82, 217 (2009); https : //doi.org/10.1134/s1070427209020 104. 


\section{ФУР'Є-ІЧ-СПЕКТРОСКОПІЯ ВИВЧЕННЯ РАДІАЦІЙНО-ТЕРМАЛЬНОГО РОЗКЛАДАННЯ} ВОДИ В СИСТЕМІ nano- $\mathrm{ZrO}_{2}+$ nano- $\mathrm{Al}_{2} \mathrm{O}_{3}+\mathrm{H}_{2} \mathrm{O}$

Т. Н. Агаєв, С. З. Мелікова, Н. Н. Гаджієва Інститут радіаційних проблем НАН Азербайджану, вул. Б. Вагабзаде, 9, Баку, АZ 1143, Азербайджан, e-mail: sevincmelikova9513@gmail.com

У цій роботі подано результати інфрачервоних спектроскопічних досліджень перетворення Фур'є радіаційно-термічного розкладання води в гетерогенній системі nano- $\mathrm{ZrO}_{2}+$ nano- $\mathrm{Al}_{2} \mathrm{O}_{3}+\mathrm{H}_{2} \mathrm{O}$ за різних вагових співвідношень нанооксидів у діапазоні температур $T=373 \div 673 \mathrm{~K} \mathrm{і} \mathrm{під} \mathrm{час} \mathrm{радіаційного} \mathrm{опромі-}$ нення. Установлено, що основними проміжними продуктами радіаційно-гетерогенного розкладання води $\epsilon$ молекулярний кисень та інші кисневмісні радикальні йонні групи, що утворюються гамма-опроміненням, а також поверхневі гідриди цирконію та алюмінію. На основі порівняльного аналізу змін інтенсивності смуг поглинання молекулярної води та поверхневих гідроксильних груп, що характеризують нано- $\mathrm{ZrO}_{2}$ та nano$\mathrm{Al}_{2} \mathrm{O}_{3}$ як функцію температури, виявлено радіаційно-каталітичну активність нано- $\mathrm{ZrO}_{2}$ за встановленого значення поглиненої дози. Визначено $W_{\mathrm{RT}}\left(\mathrm{H}_{2}\right)$ та його радіаційно-хімічні виходи $G(\mathrm{H} 2)$. Установлено стимулювальну роль у радіаційно-термічному розкладанні $\mathrm{H}_{2} \mathrm{O}$ в гетерогенній системі nano- $\mathrm{ZrO}_{2}+\mathrm{nano}^{-\mathrm{Al}_{2} \mathrm{O}_{3}}$ $(T=373 \div 673 \mathrm{~K})$.

Ключові слова: фур'є-ІЧ-спектроскопія, нано-цирконієвий оксид, нано-алюмінієвий оксид, $\gamma$ опромінення, радіаційно-термічне розкладання 